\title{
'There is no concern of prohibition against their trade': $A$ responsum by Rashbatz on the trade in monkeys practiced by Algerian Jews in the middle ages
}

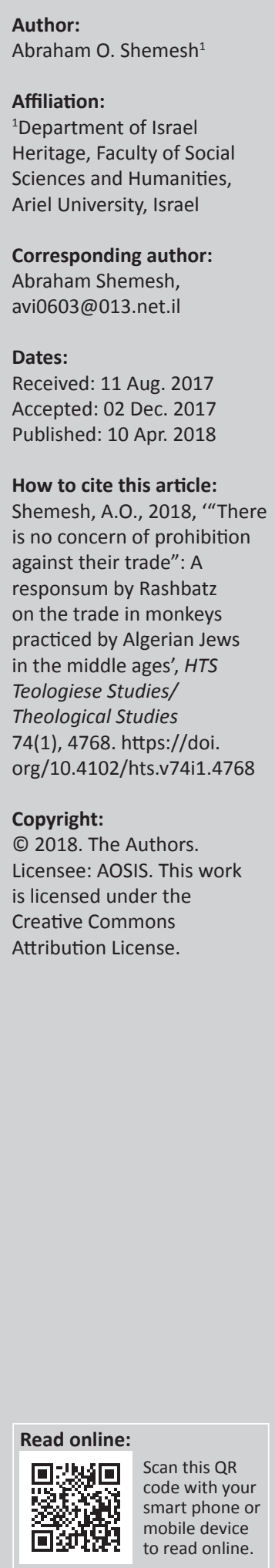

The current study deals with the responsum of R. Shimon ben Zemah Duran (Rashbatz, Algeria, 15th century), a Jewish halakhic adjudicator, on the trade in monkeys practiced by Algerian Jews in the middle ages. The basis of the discussion concerning the monkey trade is an ancient prohibition of the Mishna's sages against trading in non-kosher animals. The current study clarifies the halakhic, historical and zoological circumstances underlying the missive sent to Rashbatz. In fact, R. Shimon ben Zemah Duran permitted trading in monkeys. He bases his ruling on ancient sources in rabbinical literature and states that this is not a new issue in the economic life of Algerian Jews and that his family also dealt in the monkey trade.

\section{Introduction}

Hunting and trade in animals for an array of purposes, such as for consumption, entertainment and sport, have been practiced by humankind from time immemorial. Animals were hunted and sold in their immediate geographical territory and also exported from their natural habitats to distant foreign places. Over the generations, Jewish sources record the trade in animals in several narrative and legal contexts. The Scriptures portray Solomon's financial and military prowess, and, among other things, mention the cooperation between Solomon's fleet of ships and that of Hiram, ruler of Sidon, manifested in the import of cypress, gold, silver, ivory as well as exotic birds and monkeys to the Mediterranean basin (1 Ki 10:22; 2 Chronicles 9:21).

The practice of keeping monkeys in private homes was documented in classical literature (Morris \& Morris 1966; Pliny the Elder 1940:VIII, 80, 216, 151). Rabbinical literature also indicates that this was part of Jewish reality and that it existed not merely as a theoretical issue, for example, the Talmudic tale of a monkey who copulated with a woman 'naturally and unnaturally' (Jerusalem Talmud, Megila 4:1,75a). Reported cases include that of a monkey who created a bowl by carving a block of clay (Jerusalem Talmud, Betsa 1:3, 70b) or a monkey who dyed wool (Babylonian Talmud, Baba Kama 101a).

An interesting example of a halakhic adjudicator's discussion of the medieval monkey trade is evident from a question sent by missive to R. Shimon ben Zemah Duran (Rashbatz, born 1361), whose family was known for producing a chain of rabbis, sages and rabbinical judges over several centuries. The family originated from Provence and its descendants moved to the island of Mallorca (Majorca) near Spain (Azulai 1994:64-65; Kayserling 2002-2012; Zimmels 1971:XII, 240245). In 1391, following the decrees and the pogroms against the Jews in Spain and Mallorca, R. Shimon fled with his father and family to Algiers, capital of Algeria. He met with much acclaim there as a religious scholar and served as a rabbinical judge until his death in 1444 (on the decrees of 1391, see Hirschberg 1964:I, 84-102).

The purpose of the current study is to clarify the halakhic, historical and zoological circumstances underlying the missive sent to Rashbatz. The research questions we shall focus on are:

1. What species of monkey was traded by the Jews of Algeria? Were these local monkeys or were the Jewish merchants a link in the process that involved transporting monkeys from distant lands to their final destinations?

2. What is the ancient halakhic basis for the prohibition against trading in impure animals and how did Rashbatz cope with this prohibition in his ruling with regard to the monkeys?

3. Is it possible to reconstruct the monkey trade route and the final destinations of these monkeys? 


\section{Methodological aspects}

- The monkey trade in medieval Algeria is yet to be properly studied. This is also true of the role of Jewish North African merchants in this industry, in contrast to the trade in other animal-based products, such as ostrich feathers and coral (see later sections). One possible reason might be its very limited mention in contemporary literature. Indeed, we have only one rabbinical responsum that describes this phenomenon and its halakhic implications. Then again, the document provides us with several important historical details that might lead to a wider description of the process, albeit not to its scope.

- There are several types of information sources concerning monkeys in the middle ages. Bestiaries, a literary genre that describes real or imaginary animals; figurative finds (drawings and sculptures); and chronicles and general literature that mention them in various contexts. So far, several studies have focused on the relationship between humans and monkeys in the middle ages. Various studies, such as those of Janson (1952) and Walker Vadillo (2013), deal with the representation and symbolism of monkeys in European figurative art. Another aspect of the topic is the use of monkeys as pets by European elites (Buquet 2013; Janson 1952; Sax 2001).

The significance of these studies for our discussion is the indirect information they provide on those regions in Europe to which monkeys were brought but less on the places in North Africa from whence they were sent. Regretfully, in quite a few cases, the researchers did not refer to the species of monkey mentioned in the literary or figurative sources, and therefore the description centres only on the general context of monkeys. The texts do not always contain sufficient information that would enable identification of the species, but visual materials definitely make it possible to do so, as well as to try and detect what purposes the monkeys served and how they were kept:

- The destinations to which monkeys were sent are not mentioned in the missive sent to Rashbatz. However, some contemporary rabbinical sources describe the trade routes, and it may be assumed that the monkeys were transported together with other wares traded. Rashbatz deals with the topic of commodities and their trade routes in another of his responsa - Responsa Tashbetz.

Two other contemporary Jewish sages recorded important information on the import and export of goods from Algeria on the Mediterranean coast. The first is Ribash, R. Yitzhak bar Sheshet (born 1326), who lived and operated in Barcelona and Saragossa. In the 1391 pogroms he too moved from Spain to Algeria and met with high esteem. The second sage is Rashbash, R. Solomon ben Simon Duran, the son of Rashbatz (born about 1400). After his father's death, the Rashbash was appointed rabbinical judge of the community and his authority was recognised throughout the West. As part of his strong ties with the Algerian congregations, many questions were addressed to him, on financial and commercial issues as well.

\section{Content of the question missive and R. Shimon Duran's answer}

The missive asking about the monkey trade was addressed to Rashbatz by R. Shalom bar Yitzhak Asevili from the Algerian city of Béjaiia (بجاية). The exact date of the correspondence is not stated in the responsum, but it was clearly after 1391 . Béjaiia is a port city on the coast of the Mediterranean. This explains how Jewish merchants from Spain and Mallorca arrived there, as in other port cities, such as Breshk, Tenes and Algiers after the pogroms of 1391. It is not impossible that Asevili himself came in this way (Weinstein 1973:39).

As stated by Menachem Weinstein (1974:180-181), the Béjaïa community was one of Algeria's main long-standing Jewish communities. Rashbatz was accepted as an adjudicator not only by the new residents who had arrived in the city following the pogroms of 1391 but rather also by the oldtimers. His ties with this community were very strong and his responsa contain dozens of responses to questions on an array of topics addressed to him by this community (Epstein 1930). Shalom Asevili is not known to us from any other source. Rashbatz addresses him as 'the intellectual' (haMaskil) and this designation appears to reflect his respectable status. His surname indicates his family's origins in the city of Seville, Spain, and he was probably among the refugees who arrived in Béjaïa following the exile.

It appears that Asevili was not simply a student who sought the halakhic opinion of Rashbatz concerning a phenomenon familiar to him. He was probably a merchant who was involved in the monkey trade in practice and who had discovered that this occupation was halakhically problematic, or perhaps he was a merchant interested in becoming active in the monkey trade and wished to find out in advance whether it was halakhically permissible.

In his missive, Asevili addressed two questions to Rashbatz. One concerns carrying coins on the Sabbath and the other concerns the monkey trade. The exact wording that appears in Rashbatz's responsum, includes the question about the monkey trade and the response given by Rashbatz. The original question submitted to Rashbatz may have been lengthier, while the one we have before us in many editions of his book (such as Livorno 1782; Jerusalem 1970; 1992) includes only the gist of the matter. In any case, it is clear that Rashbatz was well acquainted with the phenomenon. He writes:

Béjaïa, To the intellectual Rabbi Shalom may God keep and revive him son of Yitzhak Asevili may God keep and revive him [...] You also asked whether it is permissible to trade in monkeys or not. Response: The root of the matter is that Is[rael] are forbidden to trade in anything that they [=non-Jews] see fit to eat and Israel are permitted to trade in anything that they do not see fit to eat $[\ldots]$ This is also true of monkeys, [which] are not fit to eat and therefore it is permissible to trade in them and there is no concern of a prohibition against their trade and several s[cholars] have traded in them and my grandfather [adoni zekeni] and my father [adoni avi] are examples of this [בדידהו הוה עובדא] and the 
Tosefta Shevi'it explicitly permits huldut ve-hatulim ve-kofim [on the identification of these animals see below]. (Rashbatz 1782:II, 25)

Rashbatz permitted trading in monkeys. He bases his ruling on ancient sources in rabbinical literature and also states that this is not a new issue in the economic life of Algerian Jews and that his family also dealt in the monkey trade. In the next few lines, I shall discuss in more detail the various aspects that arise from the responsum.

\section{The species of monkey mentioned in the responsum of Rashbatz: The Barbary macaque from the Atlas Mountains}

Monkeys were first introduced in Western Europe following the opening of trade routes with the Near East (Janson 1952:30-31,49). They were widely available in Western Europe from the 12th century (Walker-Meikle 2012:13). The main kinds of apes exported to Europe were the tailless Barbary ape, the baboons of Egypt, the African-tailed monkeys, such as the mantled guereza, and the Colobinae of India.

The monkeys discussed by R. Duran are probably Barbary macaques (Macaca Sylvanus), a local species found in North Africa (Fa 1984:12; Nowak 1991:I, 474-475). A population of this species is also found in Gibraltar, and it is, in fact, the only monkey species found in Europe (Butynski et al. 2008; Lavieren 2012). The common research assumption is that this population was brought to Gibraltar mainly as pets from about 711-1497 by the Maori people who occupied the southern part of the Iberian Peninsula (Jackson Godfrey Fothergill 1987; Modolo, Salzburger \& Martin 2005). In fact, the first written evidence of Barbary macaques on Gibraltar dates from 1704 (Modolo et al. 2005).

The distribution of the Barbary macaque was in the past much wider than at present, and it included all of North Africa, such that hunting it was easier in the time of Rashbatz (Ciani 1986; Lindburg 1980; Taub 1984:78-71). The currentday distribution of this species has been reduced to the mountainous forests in the Atlas Mountains of Algeria and Morocco (Ciani 1986; Fa 1984:8-12). This species lives naturally in troops of several dozen individuals and its habitat is forests of Atlantic cedars (Cedrus atlantica Manetti) and cork oaks (Quercus suber) (Fa 1984:12; Lavieren 2012) (Figure 1).

Barbary macaques are medium-sized monkeys; they are not excessively ungainly and are characterised by high intelligence, a quality that made it possible to train them and keep them as cultured animals throughout history. Barbary macaques have been associated with humans for thousands of years. They were found embalmed in the pyramids in Egypt (Goudsmit \& Brandon-Jones 1999) and were also found in the excavations of Pompeii (Naples, southern Italy), a city that was buried in volcanic ash when Vesuvius erupted in 79 AD (Bailey et al. 1999; King 2002). The Barbary macaque served as

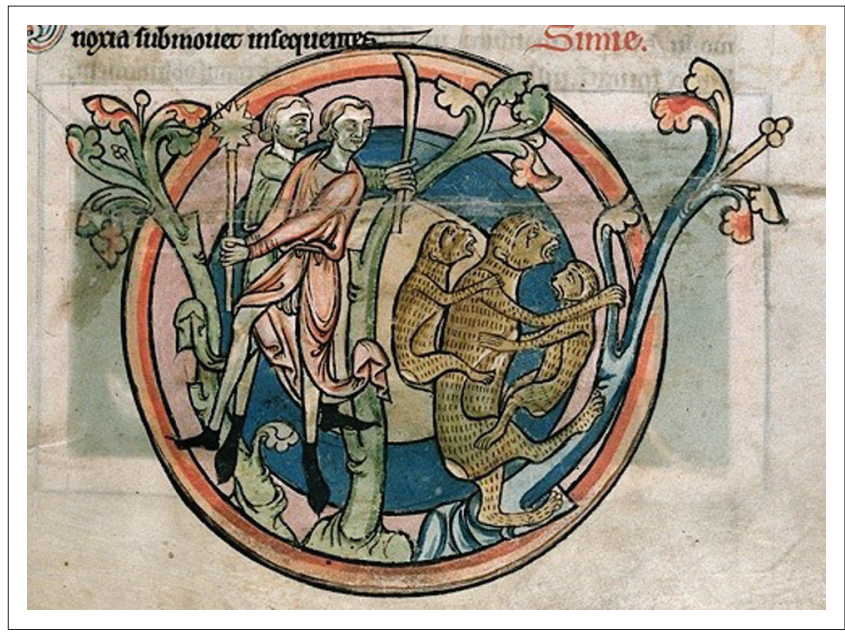

Source: Pinterst, n.d., Mother Ape with Young Pursued by Hunters. Bestiary. Salisbury (?) (England). Second half of the 13th century. London, The British Library, Ms. Harley 4751, fol. 11r., viewed n.d., from Source: https://www.pinterest.com/pin/527554543828964987/ FIGURE 1: Hunting of tailless monkeys, probably the Barbary macaque.

a friendly pet in Greek and Roman classical societies, that is, in the central and eastern side of the Mediterranean (Hughes 2003). Until the 11th-12th centuries, before the Barbary macaques arrived in Western Europe via the Mediterranean, monkeys were normally not known in these areas.

Macaca Sylvanus was perhaps the most famous primate in the Western World in medieval times (Masseti \& Bruner 2009:40). According to some scholars, the ape of medieval Western European literature is most likely the Barbary ape, or in some cases the tailed ape of tropical Africa, such as of the genus Cercopithecus (Friedman \& Figg 2000:23-24; George \& Yapp 1991:91-92). In the middle ages, Barbary macaques were animals deemed desirable by the aristocracy (Sax 2001). In France, the Barbary macaque was among the taxable exotic live goods imported and it was used for street shows and as a pet and status symbol of the elites, kept by both women and men (Paden William 2016:34) (Figure 2). Towards the 16th century, ownership of Barbary macaques spread to European lower classes as well (Thomas 1984).

\section{The halakhic precursors to Duran's responsum: An ancient rabbinical prohibition against trading in impure animals}

The sages of the Mishna and Talmud dealt with several religious prohibitions related to the trade in animals with gentiles. For example, they prohibited Jews from selling to idolaters animals, such as sheep, goats and white cocks, for concern that they might use these for their pagan rituals (Mishnah, Avoda Zara 1:5-6). In another case, they prohibited selling large cattle to gentiles for concern that they might loan or rent them to Jews for working on the Sabbath (Mishnah, Avoda Zara 1:6; Babylonian Talmud, ibid., 15a).

Underlying the question addressed to R. Shimon Duran is a Mishna and Talmud era prohibition against trading in impure 


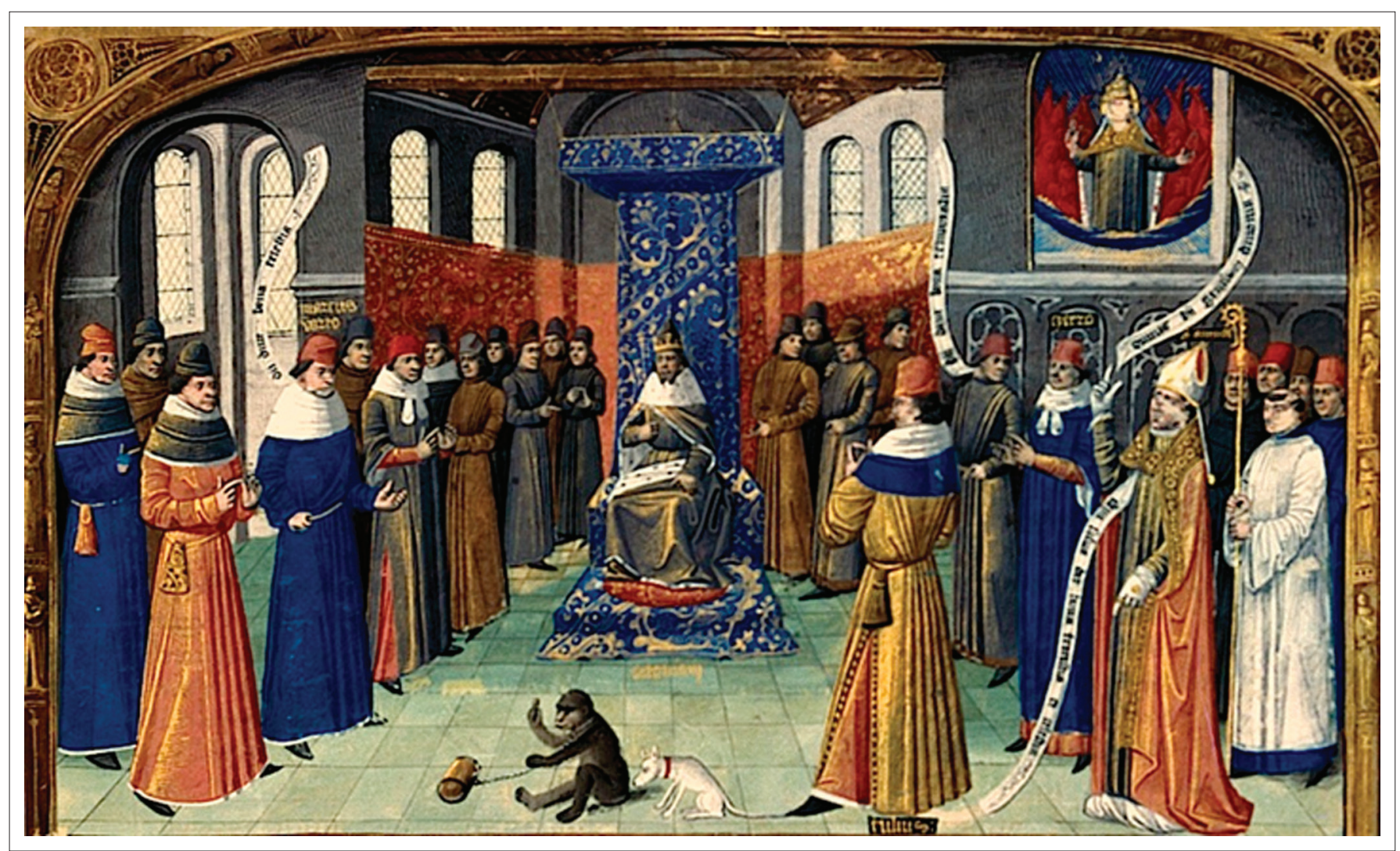

Source: Medieval Animal Data-Network, n.d., Mâcon, BM, Ms 1, f. 211, 15th Century, viewed n.d., from https://mad.hypotheses.org/707

FIGURE 2: Monkey in medieval European palace.

animals considered by non-Jewish society fit to eat, based on the concern that the Jewish merchant might eat them (see below). The Mishnah in Avoda Zara 1:7 mentions the prohibition against selling dangerous animals, such as lions and bears, to hostile nations for concern that the latter would use the animals for negative purposes. In this case, the Mishna does not mention the prohibition of trading unclean animals because these animals are not eaten.

Some of the later halakhic commentators discerned the difficulty that underlies the prohibition. One of the questions raised was why is there cause for concern that traders in these animals might eat their flesh? Why is there no similar cause for concern that ownership for purposes other than trade would result in eating them? Some claimed that the issue was food prepared from unclean animals and that the concern was that Jewish vendors would taste the food, as customary among vendors. Another explanation was the concern of mar'it ayin, that is, that people who would see the Jewish trader dealing in these animals for purposes of consumption would mistakenly assume that they are permitted for eating (Ha-Kohen 1859:8b). In my understanding, it is not impossible that the concern was that during the trader's wanderings he would encounter a state of hunger and would be compelled to eat the animals in which he was trading.

The prohibition is mentioned in two Eretz Israel literary parallels from the Roman period. The Mishna (Mishnah Shevi'it 7:3) states in general: 'One may not engage in business [...] with reptiles or with creeping things (Shekatzim u-remasim)'. The Tosefta (ibid., 5:9, Lieberman 1955:187) did not make do with a general presentation of the prohibition; rather it brought a detailed list of animals in which one may not trade: 'One may not bring village dogs (klavim kofrin), mongoose (huldot sna'im), cats (hatulin), or apes (kifot) to sell them to a gentile'. The word 'kifot' appears in the Vienna manuscript; however the Erfurt manuscript and the literature of the Rishonim (medieval rabbis) have 'kofot', that is, 'kofim', monkeys (Lieberman 1955:187).

The prohibition of selling unclean animals to gentiles was also mentioned in the Babylonian Talmud with regard to Jewish hunters: 'Hunters of beasts, birds, and fish, who chance upon unclean species, are permitted to sell them to Gentiles' (Pesachim 23a). As Rabbi Shlomo Yitzchaki (1040-1105), the famous medieval French author of the comprehensive commentary on the Talmud, explains: a hunter who happens to catch an unclean animal is allowed to sell it to gentiles, but it is forbidden to look for such animals on purpose in order to sell them to gentiles (commentary of Rashi on this source).

Other sources include a dissenting opinion. The Tosefta in Avoda Zara 2:3 brings this opinion in the name of R. Shimon ben Elazar: 'You sell dogs (klavim kofriyim), mongoose (huldot ha-sna'ot) and cats (ve-hatulot) and apes (ve-ha-kofot)' (Zuckermandel 1937:462). However, in the Tosefta, Baba Kama 8:17 (Lieberman 1955:40-41), the version is: 'You breed dogs (klavim kofrim) ... things which clean the house'. This is 
also the version of the Babylonian Talmud, Baba Kama 80a: 'It is however allowed to breed klavim kofrin, hatulin, kofin and huldoth sena'im, as these help to keep the house clean'. The Talmud brings a permissive opinion on raising these animals in the name of $\mathrm{R}$. Ishmael ben Elisha, among the greatest Tanaim of the third generation. However, as Lieberman states, the correct version is that of R. Shimon ben Elazar, a Tana of the fifth generation. Hence, according to this opinion, it is allowed to raise or keep impure animals (not to sell them!) owing to their benefits for the private household.

The lists we have before us reflect animals that served the ancients in the classical period for an array of civil purposes, that is, to 'clean' the house of pests. The list includes:

1. 'Kelev kofri' - a species of dog (Canis familiaris) that was common in rural Eretz Israel, which according to the Mishna resembled a jackal (Mishnah, Kilayim 1:6; Jerusalem Talmud, ibid., 27a; Felix 1967:117).

2. 'Huldot sna'im' - Talmudic zoology scholars identify this term with several small carnivorous mammals, such as the mongoose (Herpestes ichneumon) or Stone Marten (Martes foina syriaca) (Dor 1997:73; Felix 1971:51).

3. Cats - domestic cats (Felis Lybica domestica).

The animals mentioned have in common their utilisation in ancient times to eliminate rodents and pests in the home, such as mice, rats and snakes (Babylonian Talmud, Baba Kama 80b).

The version of the Tosefta available to R. Shimon Duran included monkeys, and accordingly he contends that an ancient halakhic source explicitly permits keeping monkeys. Rashbatz claims that the permission to sell monkeys was mentioned in Tosefta Shevi'it although, as we saw above, according to the versions available to us, this source rejects trading in these animals (Lieberman 1955:187).

The Vienna manuscript of the Tosefta Shevi'it has 'kifot' and maybe this meant 'kipod', that is, hedgehog (Erinaceus sp.). The word 'kipod' appears explicitly in the version of the Tosefta published with the Vilna Talmud (Shas Vilna), Reem press $1886,17 \mathrm{a}$, and it too might have been used to overcome pests in the home. Hedgehogs are useful mammals as they eat snails and insects, which harbour many pests, and hence their use to 'clean the house' (on this version, see Lieberman 2000:553).

R. Shimon Duran states that beyond the explicit permission given in the Tosefta, the fundamental justification for permitting dealing in the monkey trade is the fact that the prohibition applies only to impure animals that the surrounding society considers fit to eat. The claim that something which is not eaten may be traded, although theoretically not kosher, is not Duran's own innovation. It was already stated by the Jerusalem Talmud, Baba Kama 7:3, 6a:

Anything that is prohibited based on their [the sages] decision, may be traded, as a donkey is raised for its work and a camel is raised for its work [and not for eating, and therefore there is no concern that the trader will eat it].

This understanding was mentioned also by medieval rabbis before Duran, such as the Tosafists from France and Germany who created critical and explanatory glosses on the Talmud: 'And any fat may be sold as it is not ready for eating [...] [and also] horses and donkeys can be traded as they are normally used for work' (Baba Kama 82b, from 'One shall not breed pigs').

Accordingly, monkeys are not used for this purpose, and therefore the prohibition against trading does not apply. Eating monkeys is customary in traditional societies in the Far East and among African tribes; however, according to Duran's responsum, this culinary custom was not practiced in his time in North African countries, including Algeria. Notably, in the classical period, the Barbary macaque was eaten in Tunisia and Libya but not in Morocco and Algeria because of its veneration (Fa 1984:6). In modern times as well it is occasionally eaten, but this is a marginal and rare occurrence (Deag 1977).

\section{The monkeys' estimated destination}

R. Duran's responsum contains no information about the destinations to which the monkeys were sent. As stated, it is to be assumed that they arrived at Mediterranean ports together with other exports of which we have historical knowledge, for example, wheat (Rivash 1547:178, 185), gold (Tashbetz 1738:III, 74) and animal skins (Rashbash 1742:179), as well as other wares from the animal world originating from Algeria, that is, coral harvested from the sea (Rashbash 1742:179; Rashbatz 1782:II, 13) or ostrich feathers from ostriches living in desert regions of North Africa (Avitbol 1993:62, 66; Bashan 2000:282; Tashbetz 1738:III, 115; Weinstein 1974:42-43).

Commerce in Algeria in the time of Rashbatz was divided into three types: local commerce, national commerce and international commerce (Weinstein 1974:39). Monkeys appear to have had a greater financial value specifically in international commerce and particularly in European markets for three main reasons: (1) There were no monkeys on this continent, aside from the little population of macaques in Gibraltar; (2) the Barbary macaque populations were the most accessible and the closest to Europe and it was possible to transport them from North African ports in a relatively short distance and time, a process that could have ensured that the monkeys would not die on the way; and (3) the demand for monkeys in European countries. There was undoubtedly also an internal trade in monkeys, as there is to this day (Lavieren 2004; 2012), but the testimonies we have of the demand for or keeping of Barbary macaques by rulers and affluent people in European countries indicate the northern trade's significance.

European sources from the 11th and 12th centuries to the 15th century mention the practice of keeping monkeys (in general) 


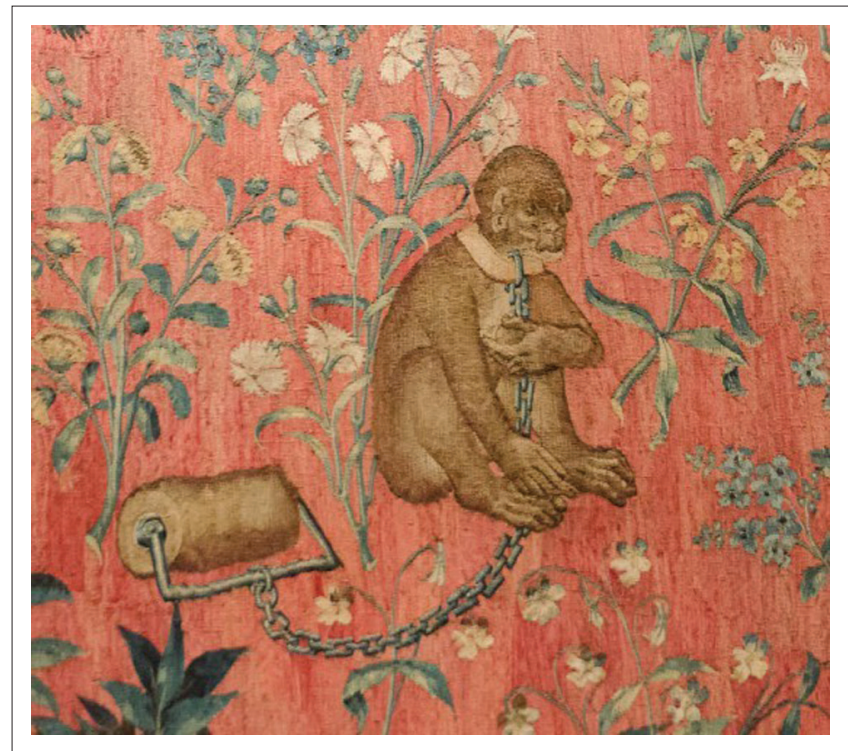

Source: Pinterst, n.d., Detail of the Tapestry of the Lady and the unicorn, Musée de Cluny, Paris, viewed n.d., from https://www.pinterest.com/pin/527554543828964998

FIGURE 3: Barbary Macaque; Detail of the Tapestry of the Lady and the unicorn, Musée de Cluny, Paris, circa 1500.

as customary in various countries, such as France, Italy and Germany (Buquet 2013; Paden William 2016:34; Wich \& Marshall 2016:133, see also Figure 3). Archaeological evidence of the remains of Barbary macaques from the classical period and the Middle Ages was found throughout England as well (Lynn 1997; Walker-Meikle 2012:31). This indicates that monkeys that arrived in Europe were transported to distant regions in the south and centre of the continent.

Algerian Jews had an important role in the trade with foreign countries, which took place by sea in the 15th century, mainly with Spain and Mallorca. Indeed, ships of merchants from Venice and Genoa (in Italian: Genova), a port city in northern Italy, also came to Algeria; however, these were rare, unlike the ships from Spain and Mallorca that arrived more frequently (Rashbash 1742:214; Tashbetz 1738:III, 166).

The Barbary macaque indeed spread extensively to Italy via the Mediterranean (Hill 1966), but historical records of this in the rabbinical literature attest to secondary trade. Some of the monkeys were transported by ship directly to Mediterranean ports, for example, to Italy and southern France, but monkeys that arrived on the coast of southern Spain may be assumed to have been transported by land to continental markets. Assuming that Asevili was a merchant of Spanish origins, he would obviously have enjoyed an advantage when selling monkeys in Spain (familiarity with the language, people and markets). Furthermore, he settled in Béjaïa, which was a port city, from whence he could trade with Spain and Mallorca. Indeed, as Janson (1952:30) noted, the western part of the Mediterranean had a very prominent role in transporting monkeys to Europe.

The responsa literature written by the rabbis of Algeria indicates various forms of international trade. Some merchants came in Spanish ships and purchased goods at one of the port cities, while others appointed an agent to travel to Spain with the wares and sell them there (Weinstein 1974:41). R. Yitzhak bar Sheshet Perfet (1326-1408) reports that the Jews of Honain (today: Honaine), a town in Tlemcen Province in northwestern Algeria, exported wheat by sea to Christian Europe (eretz edom), probably Spain, resulting in the Muslim claim that they strengthen 'the idolaters' against them (Rivash 1547:178). According to Jewish law, mourners are forbidden to work in the 7 days after the funeral. R. Shlomo ben Shimon Duran (1400-1467) allowed a merchant who was in mourning to have his partner sell goods to ships of merchants from Venice and Genoa, because the latter were rare and if he were to refrain from selling the goods he would lose his money (davar ha-aved). However, ships to Spain and Mallorca arrived more frequently, so mourners could wait and sell their goods after the period of mourning (Rashbash 1742:214).

We also know of merchants who collaborated, where one merchant resided in Mallorca and sent merchandise to his partner in Algiers, or a merchant from Béjaïa who travelled to a 'distant country' (medinat ha-yam) and appointed an agent to represent him in Béjaïa. This agent received and sent goods to the merchant overseas (Weinstein 1974:41).

According to the testimony of Rashbatz, both his father and his grandfather traded in monkeys, and they may have been involved in this industry even when living in Spain before the 1391 pogroms. It is not impossible that the monkey trade was a financial industry dominated by certain families. The extent of the Jewish trade in monkeys is unknown, as is the amount of monkeys sent overseas. Assumedly, this involved shipments of only a small number of monkeys.

\section{Conclusion}

The export of monkeys from Africa and the Mediterranean to Europe continued for many years. Most of the information we have about this are European sources that relate how the monkeys were used by the elites in Italy, France and Germany. The historical contribution of the responsum given by Rashbatz is its identification of the 'sellers', that is, the merchants who sent the monkeys to Europe. Moreover, the responsum reveals a less familiar aspect that pertains to the role of the 15th century Algerian Jews in the monkey trade. These were apparently merchants of Spanish origin who immigrated to Algeria and may have engaged in this field even when living in Spain and Mallorca. To our understanding, Shalom Asevili was a merchant from Béjaiia, a port city on the Mediterranean coast, from whence he arranged the sale of the monkeys. Rashbatz reveals an interesting detail when he relates that his father and grandfather sold monkeys too, that is, rabbinical scholars took part in the monkey trade. It is not clear whether they did so while still living in Mallorca, but it appears that this work remained in the family for at least two generations, and the knowledge and practical aspects may have been handed down from father to son.

The question missive and the responsum of Rashbatz reveal that monkeys were not used as a source of food but rather, 
according to Christian chronicles, for purposes of entertainment and as a social status symbol. Rashbatz used this justification to permit the monkey trade. We assume that the monkeys were probably Barbary macaques, a species that lives in the Atlas Mountains to this very day. These monkeys were accessible to North African hunters and merchants and could be transported to Europe through the existing trade routes. The Barbary macaque was a likeable and common species in Europe.

The basis of the discussion concerning the monkey trade is an ancient prohibition of the Mishna's sages against trading in non-kosher animals. The halakhic responsum of Rashbatz is a classic example of the advantages of the responsa literature as a historical source, but it also shows its disadvantages (Soloveitchik 1990). The rabbinical responsum does not provide sufficient details in order to establish historical facts, rather the information contained in it must be completed or crossed-checked with general contemporary historical sources. By virtue of being a halakhic source interested in conveying a religioustheological message, the responsum of Rashbatz focuses on the halakhic question of whether the monkey trade is permissible or prohibited. Hence, it attests to the existence of this trade and to a certain degree also to those who engage in it, but does not provide essential information as to the species sold, the regions in which they were hunted or their trade routes from the ports of North Africa to Europe.

This article suggests the need for more extensive exploration of this economic industry among North African Jews. In order to complete the historical picture, it is necessary to uncover new rabbinical and historical sources that might expand and further establish our knowledge of the subject.

\section{Acknowledgements Competing interests}

The author declares that he has no financial or personal relationships which may have inappropriately influenced him in writing this article.

\section{References}

Avitbol, M., 1993, Tujjar al-Sultan: Jewish economic elite in Morocco, Ben Zvi Institute, Jerusalem. [Hebrew]

Azulai, H.Y.D., 1994, Shem ha-Gdolim ha-Shalem, Otzar ha-Sefarim, Jerusalem [Hebrew]

Bailey, J.F., Henneberg, M., Colson, I.B., Ciarallo, A., Hedges, R.E.M. \& Sykes, B., 1999, 'Monkey business in Pompeii: Unique find of a juvenile Barbary Macaque skeleton in Pompeii identified using osteology and ancient DNA techniques', Molecular Biology and Evolution 16, 1410-1414. https://doi.org/10.1093/oxfordjournals. Biology and Evolutic
molbev.a026051

Bashan, E., 2000, Moroccan Jewry: Its past and culture, Kibbutz ha-Mehuchad, Tel Aviv. [Hebrew]

Buquet, T., 2013, 'Preventing “Monkey business": Fettered apes in the Middle Ages', Medieval Animal Data Network (blog on Hypotheses.org), viewed 23 June 2013, from, http://mad.hypotheses.org/37

Butynski, T.M., Cortes, J., Waters, S., Fa, J., Hobbelink, M.E., van Lavieren, E. et al., 2008, Macaca sylvanus. The IUCN red list of threatened species, Version 2014.2, viewed 28 March 2014, from www.iucnredlist.org

Ciani, A.C., 1986, “'La Macaca sylvanus” in Marocco: Sopravvivenza. o estinzione. Osservazioni personali e dati storico-demografici', Antropologia Contemporanea 9(2), 117-132.
Deag, J., 1977, 'The status of the Barbary Macaque Macaca sylvanus in captivity and factors influencing its distribution in the wild', in H.S.H. Rainier, Prince of Monaco \& G. Bourne (eds.), Primate conservation, pp. 267-287, Academic Press, New York.

Dor, M., 1997, Animals in Biblical, Mishnah and Talmudic periods, Grafor-Deftel, Tel Aviv. [Hebrew]

Epstein, I., 1930, The Responsa of rabbi Simon B. Zemah Duran as a source of the history of the Jews in North Africa, Oxford University Press, Oxford.

Fa, J.E., 1984, 'The Barbary Macaque', in J.E. Fa (ed.), The Barbary Macaque: A case study in conservation, pp. 3-15, Plenum, New York.

Felix, Y., 1967, Mixed sowing breeding and grafting, Dvir, Tel Aviv. [Hebrew]

Felix, Y., 1971, The animals in the Mishnah: The description and the identification of the animals in the Mishnah, The institute of the Mishnah Research, Jerusalem. [Hebrew]

Friedman, J.B. \& Figg, K.M., 2000, Trade, travel and exploration in the middle ages, Routledge, New York.

George, W. \& Brundson, Y., 1991, The naming of the beasts: Natural history in the medieval bestiary, Gerald Duckworth \& Co Ltd, London.

Goudsmit, J. \& Brandon-Jones, D., 1999, 'Mummies of olive baboons and Barbary Macaques in the baboon catacomb of the sacred animal necropolis at north Saqqara', Journal of Egyptian Archaeology 85, 45-53. https://doi.org/10.2307/ 3822426

Ha-Kohen, S.b.M., 1859, Sifte Kohen, Gedruckt bei Gruber \& Longrien, Königsberg.

Hill, W.C.O., 1966, Primates: Comparative anatomy and taxonomy, Volume 6, catarrhini cercopithecoidea cercopithecinae, Edinburgh University Press, Edinburgh.

Hirschberg, H.Z., 1964, The history of the Jews in North Africa: The Jewish distribution in the Maghreb from the ancient time until our time, Mossad Bialik, Jerusalem. [Hebrew] viewed 30 September 2017, from http://www.jewishencyclopedia. com/articles/5366-duran\#anchor8

Hughes, J.D., 2003, 'Europe as consumer of exotic biodiversity: Greek and Roman times', Landscape Research 28(1), 21-31. https://doi.org/10.1080/014263 90306535

Jackson Godfrey Fothergill, W., 1987, The Rock of the Gibraltarians: A history of Gibraltar, Fairleigh Dickinson University Press, NJ.

Janson, H.W., 1952, Apes and ape lore in the middle ages and the renaissance, The Warburg Institute, University of London, London.

Kayserling, M., 2002-2012, 'Simon b. Zemah Duran (RaShBaZ)', in J. Jacobs (ed.), Jewish encyclopedia, Funk \& Wagnalls Company, New York.

King, A., 2002, 'Mammals: Evidence from all paintings, sculpture, mosaics, faunal remains, and ancient literary sources', in W. Feemster Jashemski \& F.G. Meyer (eds.), The natural history of Pompeii, pp. 401-450, Cambridge University Press, Cambridge.

Lavieren, E.V., 2004, 'The illegal trade in the Moroccan Barbary macaque (Macaca sylvanus) and the impact on the wild population', Thesis MSc Primate Conservation, Oxford Brookes University, Oxford.

Lavieren, E.V., 2012, 'The Barbary macaque (Macaca sylvanus); A unique endangered primate species struggling to survive', Revista Eubacteria 30, 1-4.

Lieberman, S., 1955, Tosefta, Jewish Theological Seminary, New York.

Lieberman, S., 2000. Tosefta ki-Fshuta, Jewish Theological Seminary Press, New York.

Lindburg, D.G., 1980, The macaques: Studies in ecology, behavior and evolution, Van Nostrand Reinhold Company, New York.

Lynn, C.J., 1997, Excavations at Navan Fort 1961-71, County Armagh, D.M. Waterman (ed.), Northern Ireland Archaeological Monographs, No. 3, Stationery Office, Belfast.

Masseti, M. \& Bruner, E., 2009, 'The primates of the western Palearctic: A biogeographical, historical, and archaeozoological review', Journal of Anthropological Sciences 87, 33-91.

Medieval Animal Data-Network, n.d., Mâcon, BM, Ms 1, f. 211, 15th Century, viewed n.d., from https://mad.hypotheses.org/707

Modolo, L., Salzburger, W. \& Martin, R.D., 2005, 'Phylogeography of Barbary macaques (Macaca sylvanus) and the origin of the Gibraltar colony', Proceedings of
the National Academy of Sciences of the United States of America 102(20), 7392-7397. https://doi.org/10.1073/pnas.0502186102
the National Academy of Sciences of the United States

Morris, R. \& Morris, D., 1966, Men and apes, McGraw-Hill, New York.

Nowak, R.M., 1991, Walker's mammals of the world, 5th edn., The Johns Hopkins University Press, Baltimore.

Paden William, D., 2016, Two medieval Occitan toll registers from Tarascon, Toronto University Press, Toronto.

Pinterst, n.d., Detail of the Tapestry of the Lady and the unicorn, Musée de Cluny, Paris, viewed n.d., from https://www.pinterest.com/pin/527554543828964998

Pinterst, n.d., Mother Ape with Young Pursued by Hunters. Bestiary. Salisbury (?) (England). Second half of the 13th century. London, The British Library, Ms. Harley 4751 , fol. 11r., viewed n.d., from https://www.pinterest.com/pin/5275545438289 64987/

Pliny the Elder, 1940, Natural history, volume III, Libri VIII-XI, H. Rackham (ed.), Loeb Classical Library 353, William Heinemann-Harvard University Press, London.

Rashbash, 1742, R. Shlomo ben Shimon Duran, Rashbash Responsa, Dfus Rafael Meldola, Livorno.

Rashbatz, 1782, R. Shlomo ben Zemah Duran, Yachin u-Boaz Responsa, Kastilio and Sa'adon, Livorno. 
Rivash, R., 1547, Yitzhak bar Sheshet Perfet, Rivash Responsa, Renaissance Hebraica Collection, Konstantinopel.

Sax, B., 2001, The mythical zoo: An encyclopedia of animals in world myth, legend, and literature, ABC-Clio, Santa Barbara, CA.

Soloveitchik, H., 1990, The use of Responsa as a historical source, Zalman Shazar Center for Jewish History and Hebrew University of Jerusalem, Jerusalem. [Hebrew]

Tashbetz, 1738, R. Shlomo ben Zemah Duran, Tashbetz Responsa, Dfus Naftali Hirtz ha-Levi, Amsterdam.

Taub, D.M., 1984, 'A brief historical account of the recent decline in geographic distribution of the Barbary Macaque in North Africa', in J.E. Fa (ed.), The Barbary Macaque: A case study in conservation, pp. 71-78, Plenum, New York.

Thomas, K., 1984, Man and the natural world: Changing attitudes in England, 1500-1800, Penguin Books, London.
Walker-Meikle, K., 2012, Medieval pets, Boydell Press, Woodbridge.

Walker Vadillo, M.A., 2013, 'Apes in mediaeval art', Medieval Animal Data Network (blog on Hypotheses.org), viewed 28 October 2013, from http://mad.hypotheses.org/172

Weinstein, M., 1973, 'The historical continuity of the Jewish communities in Algeria', in H.Z. Hirschberg (ed.), mi-Mizrach u-Ma'arav: Collection of researches on the history of the Jews in East and West, pp. 37-57, Bar Ilan University, Ramat Gan. [Hebrew]

Weinstein, M., 1974, 'The Jewish communities in Algeria between 1300-1830', Dissertation, Bar Ilan University, Ramat Gan. [Hebrew]

Wich, S.A. \& Marshall, A.J.', 2016, An introduction to primate conservation, Oxford University Press, Oxford.

Zimmels, Z.J., 1971, 'Durani', in I. Leibowitz (ed.), The Hebrew encyclopedia, pp. 240-245, Encyclopedia Publishing Company Ltd., Jerusalem.

Zuckermandel, M.S., 1937, Tosefta, Bamberger and Wahrmann, Jerusalem. 